\title{
The mobility of 'creative workers' and their potential contribution to the recovery of old industrial cities in Spain
}

\begin{abstract}
Strategies of attraction and retention of talent are gaining importance in the policy agendas of Spanish old industrial cities. However, since more evidence is needed regarding the effectiveness of these approaches this study begins by analysing the stocks and flows of 'creative workers' within the urban system. The inspection of a sample of their working histories confirms the capacity of this workforce to transform the nine studied cities by upgrading local human capital levels, fostering pecuniary externalities or improving local institutional frameworks. Nevertheless, some of these effects appear somehow blurred by low-skilled immigration and the dualisation of the labour market.
\end{abstract}

Keywords: urban shrinkage, talent, mobility, labour trajectories, urban resilience

\section{Introduction}

Innovation and creativity have been emphasised as the main drivers of urban development in the context of globalisation and the cultural-cognitive economy (Scott, 2008). This has important implications for cities striving to 'reinvent' themselves in the context of global economic restructuring (Bontje and Musterd, 2008), including the outstanding case of old industrial cities. These have been characterised in the international literature by long-term population decline and symptoms of economic structural crisis (Fol and Cunningham-Sabot, 2010; Power et al., 2010).

Although some interrelated effects of urban shrinkage do not offer the best preconditions for a recovery based on culture and creativity (i.e. out-migration, lack of job opportunities or initial physical urban decay), many old industrial cities started some time ago to use urban cultural policy within their revitalisation strategies to support the transition toward a 'post-industrial city' (Aber and Yahagi, 2014). Nowadays programmes that attempt to promote knowledge-intensive activities and creative industries, and attract talent or correct the mismatch of skills are increasingly presented in planning policies, especially when targeting new sources of growth in the demographic change scenario (Ploger and Weck, 2014; Pallagst et al., 2014). Nevertheless, the effectiveness of such approaches has sometimes been questioned (Musterd and Gritsai, 2012; Houston et al., 2008). The doubts extend to the welldocumented criticism of the ideas of Richard Florida about the importance of attracting the so-called 'creative class' for contemporary urban development (see, for example, Boschma and Fritsch, 2009). 
This paper aims to shed light on the controversy by looking at the stock and flow of 'creative workers' (defined by sectors or occupations) in old industrial cities in Spain. In order to control internal differences, the analysis focuses on a more homogeneous group of nine cities on the Spanish north coast with between 40,000 and 250,000 inhabitants. Despite the fact that talent attraction and retention policy strategies are in their infancy in most of these cities, their interest demonstrates the need to overcome the traditional vision of declining cities as mere sources of human capital for growing regions. Therefore, the main questions to be answered are: How well supplied are these cities with creative workers? What is the role of these cities in the human capital migration patterns in the urban system? What could be the potential impact of these workers on local economies based on to their socioprofessional profile?

In what follows we first discuss the multidisciplinary theoretical bases of the research, which look at the determinants of human capital migrations and their potential impacts on old industrial cities. The third section offers a brief methodological commentary on the Spanish Continuous Sample of Working Histories (CSWH), which was used to examine approximately 700,000 labour trajectories. Sections four and five contain respectively the aggregated analysis of talent flows and the characterisation of the creative workers' profiles. The last section summarises the main findings.

\section{Attracting forces and the regional impact of talent: a multidisciplinary theoretical framework}

The consideration of human capital, or 'talent', as one of the main drivers of urban/ regional competitiveness in the cultural-cognitive economy (Scott, 2008) has generated a wide multidisciplinary debate. In a first (micro)economic-based approach, migration is considered an individual's choice of investments in human capital based on expected returns and costs. As a result, personal characteristics would be the main factor driving the migration process. Within a context of uncertainty and the high cost of acquiring information, the evidence suggests that the propensity to migrate decreases with age (and with the number of young children living at home), while women are initially less prone to migrate (or more conditioned by couples' decisions) (EFILWC, 2006). At the same time, the willingness to move seems clearly higher for young and skilled workers, especially for those educated in a different region or country of birth (Da Vanzo and Morrison, 1981). In contrast, some other authors state that qualified people may have a greater chance of being employed in their regions (Shioji, 2001).

This theoretical perspective has been criticised since it seems to be ignoring the 'bounded mobility' framework (EFILWC, 2006), which states that mobility decisions are not isolated decisions, but rather are taken within a predefined geographical and relational context. Cultural and welfare factors, like family-based relations and social 
networks, would explain the lower propensity to migrate in Southern European countries.

A second (macro)economic-based approach considers human capital flows, a decisive factor in regional performance, as an aggregated outcome of individual decisions. Faggian and McCann (2009) describe a first scenario, where specific destination regions - dominant cities - increasingly benefit from net inflows of highly qualified individuals at the expense of other source regions - basically those regions with a declining population - which simultaneously exhibit net outflows. Following Shapiro (2006), gains in productivity will take place in the destination regions, thanks to the higher propensity to migrate of more highly trained workers. The arrival of qualified workers, attracted by employment opportunities and higher salaries, would favour the appearance of knowledge spillovers and pecuniary externalities (the 'composition effect') and would bring to the area more investments in knowledgebased activities ('scale effect'). At the same time, the quality of urban life tends to improve mainly via a growing demand for urban amenities, albeit upgrading the local institutional framework may contribute as well. Such cumulative growth mechanisms could become cumulative declines in regions characterised by the out-migration of skilled workers. However, in a second scenario, net inflow of particular types of qualified individuals would tend to replace people from other groups that exhibit net outflows from the same region, as a result of social mobility and human capital acquisition processes.

The need for more evidence about lagging regions' trends makes it worthwhile to look at the geographic- and planning-oriented approaches that deal with the causes and effects of urban shrinkage. As repeated in the international literature, globalisation, the ICT revolution and the crisis of the Fordist production system have threatened the future of European old industrial urban regions, whose industrialbased model collapsed some decades ago (Fol and Cunningham-Sabot, 2010). Regardless of whether these cities are in a phase of decline, resurgence, or somewhere in between (Power et al., 2010), the importance of talent seems undisputed in the challenge of achieving redevelopment (Kempner, 2008; Houston et al., 2008).

Nevertheless, the capacity of these cities to attract and retain talent may be impaired in some ways. Their economic profile is usually characterised by intense mono-specialisation, typically in traditional industries, mining or port activities. The restructuring of these sectors has caused a dramatic workforce reduction for which, in many cases, the service economy has not yet compensated. Furthermore, the assumption that people are ready to move where jobs are available might be not too realistic in regions undergoing economic restructuring. Sjaastad (1962) already suggested a link between long periods of unemployment for low-skilled workers and low-income groups and the risk of becoming 'locked into' an immobile situation in a lagging region. On the other hand, an industrial structure that has often been shaped by the presence of big public companies is often an obstacle to innovation and entrepreneurship in the present. 
In summary, the shortage of job opportunities became the first factor used to explain the intense out-migration of young qualified workers to growing areas. With this came a worsening of demographic trends such as low birth rates and ageing, or those affecting social diversity and cohesion, in line with the 'soft factors' identified by Florida (2005). On the other hand, the physical decay of the urban space usually affects the real estate market while falling prices tie homeowners to their locations (Sjaastad, 1962), similarly to people living in social housing (EFILWC, 2006). The city's attractiveness may also be damaged due to the proliferation of derelict buildings, wastelands and vacant houses, not to mention the possible dismantling of infrastructures and services, especially modern amenities, such as cultural and leisure facilities (Ploger, 2013).

\section{Studying creative workers' trajectories through the CSWH}

Our analysis utilises the CSWH, a yearly sample made up of four per 100 people who have been registered in the Spanish Social Security system during the reference year (therefore, a raising factor of 25). For this research, longitudinal data of occupied salaried and self-employed workers has been used, resulting in a final sample of 708,102 individuals in the whole country.

The identification of 'creative workers' is based on the two main criteria used in the literature: sectors (understanding creativity as a corporate asset) and occupations (as an attribute of the workforce). In the first case we use a comprehensive definition that includes creative sectors and other knowledge-intensive industries (Musterd and Gritsai, 2012) (see Table 1). Alternatively, the two highest workers' categories have been used to identify what we have called 'creative occupations': 'engineers, university graduates, senior management' and 'technical engineers, qualified assistants'. The workers' categories information is only available for salaried workers.

Location information in the CSWH is only available for municipalities with more than 40,000 inhabitants. In this regard, a previous test confirmed that all cities over 40,000 inhabitants are well represented in the CSWH: the average of the differences between the total employment and the estimated figures is only 5.62 per cent, with these residuals showing an approximately normal distribution. Although these municipal data allow the identification of individual old industrial cities, a complete understanding of talent flows would require an analysis at an urban area scale.

In order to simplify the analysis, only the location changes between the years 2007 and 2011 were compared (ignoring the intermediate years). On the other hand, the geographical origin of workers (by region and countries of birth) is used in the characterisation of their socio-professional profiles, in addition to some other parameters that make it possible to study the potential impact of human capital on the local economies: education levels (tertiary education) and the income of workers (although this is capped at a specific maximum limit in the original data). 
Table 1 Selection of knowledge- intensive and creative industries by NACE rev. 2

\begin{tabular}{|l|l|}
\hline Creative industries & \\
\hline Radio and TV & 601,602 \\
\hline Music and visual and performing arts & 900 \\
\hline Video, film, music production and photography & $182,591,592,742$ \\
\hline Publishing & 581,639 \\
\hline Advertising & 731 \\
\hline Software & 582,620 \\
\hline Arts and antiques trade & $910,321,322,237$ \\
\hline Architecture & 711 \\
\hline Design & 741 \\
\hline & \\
\hline Knowledge-intensive industries & \\
\hline Law and other business services & $691,692,701,702,732,781,823$ \\
\hline R\&D and Higher education & $721,722,854$ \\
\hline Financial services & $641,642,643,649,651,652,653,661,662$, \\
\hline Information and communications technology (ICT) & 663 \\
\hline
\end{tabular}

Source: Authors' elaboration

\section{Stocks and flows of creative workers in old industrial cities}

The long-term demographic trend (1981-2011) confirms the predominance of growing cities over declining cities, which is coherent with the general context of economic bonanza and the intense international immigration observed since the late 1990s until the economic crisis (see Figure 1). In this context, previous studies in Spain have confirmed that old industrial cities represent a particular case of declining cities. Although some of them have recovered their dynamism, the economic downturn and lack of expectations continue to affect many others (Sanchez-Moral et al., 2012). In order to reduce spatial heterogeneity this study focuses on the group of old industrial cities with more of 40,000 inhabitants and located in four regions along the north Atlantic arc: Ferrol in Galicia; Aviles, Langreo and Mieres in Asturias; Torrelavega in Cantabria; and Barakaldo, Basauri, Portugalete and Santurzi in the Basque Country (see Figure 1). This group has been differentiated from the more heterogeneous group of other declining cities (e.g. cities affected by suburbanisation processes). 


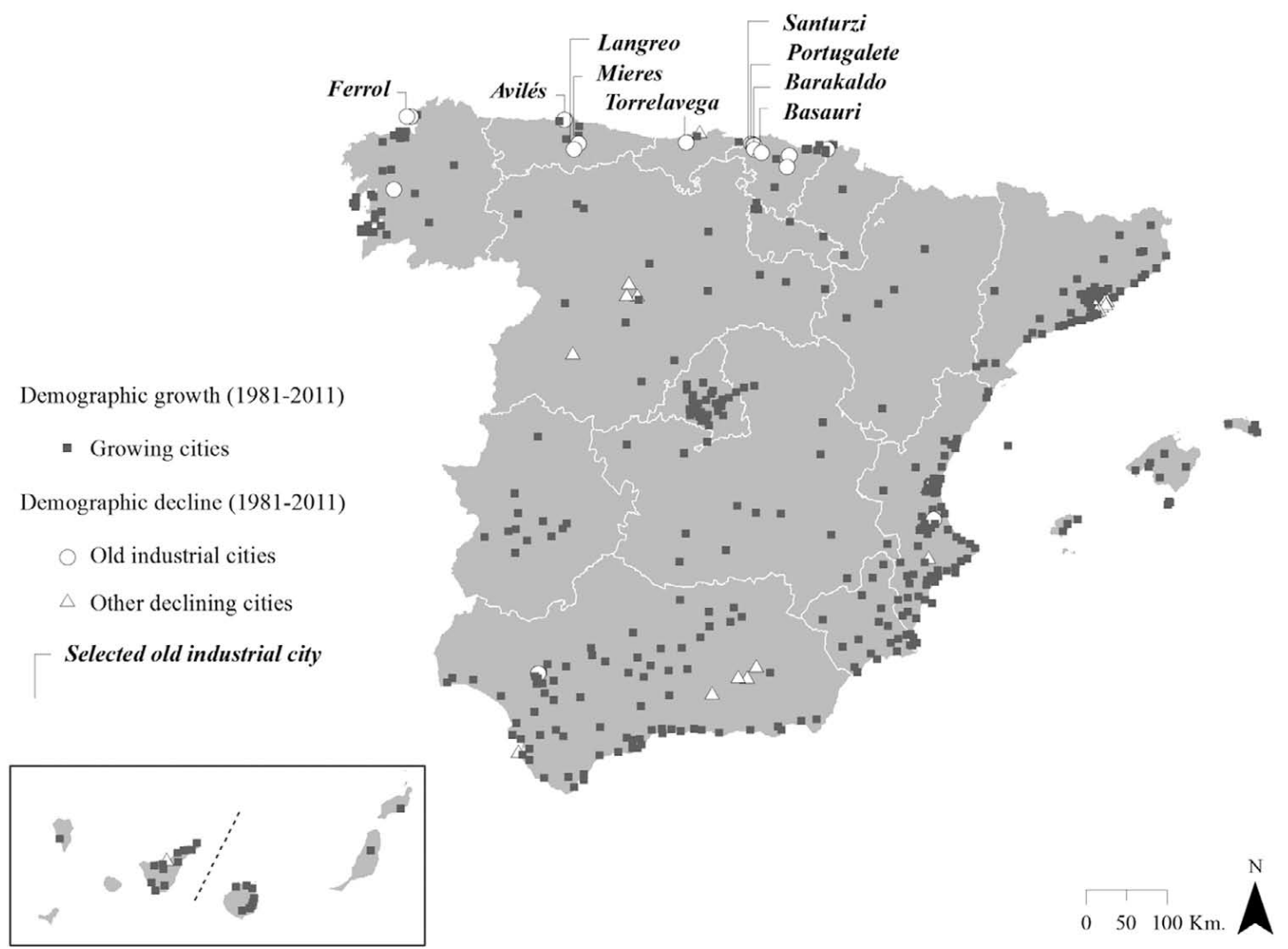

Figure 1 Long-term demographic and economic trajectories of Spanish cities with over 20,000 inhabitants

Source: Authors' elaboration on National Census data (1980-2011)

These nine old industrial cities only represent 1.13 per cent of the total population in 2011. Even though some of the most negative demographic trends of the country are observed in this group, there are differences in terms of stages of recovery (Table 2). Clearly, the main contrast corresponds to the city of Barakaldo, just on the threshold of 100,000 inhabitants, where the migratory balance as well as natural growth are positive (remarkably, the latter has turned positive for first time since 1991). The rest have negative trends in one or both of these demographic growth components. At the same time Barakaldo and the neighbouring cities of Portugalete and Santurzi display the lowest shares of employment in the manufacturing sector (which is greater than 20 per cent or even 30 per cent in other cities), thus confirming that the reconversion of their local productive systems has been achieved. The re-established dynamism, which is also visible in other real estate market indicators, is underpinned by a stronger position within the metropolitan area of Bilbao (an international example of a city that has made the transition to a knowledge-based economy). 
Table 2 Basic indicators of selected old industrial cities

\begin{tabular}{|c|c|c|c|c|}
\hline City & $\begin{array}{l}\text { Population } \\
\text { (2011) }^{(1)}\end{array}$ & $\begin{array}{c}\text { Population } \\
\text { change } \\
(1980-2011)\end{array}$ & $\begin{array}{c}\text { Natural growth } \\
\text { (individuals) } \\
(2010)^{(1)} \\
\end{array}$ & $\begin{array}{l}\text { Migratory balance } \\
\text { (individuals) (2010) }\end{array}$ \\
\hline Barakaldo & 100,064 & $-14.78 \%$ & 97 & 742 \\
\hline Basauri & 41,777 & $-19.65 \%$ & -53 & -204 \\
\hline Portugalete & 47,698 & $-17.10 \%$ & -106 & -8 \\
\hline Santurzi & 47,101 & $-11.68 \%$ & 27 & -23 \\
\hline Langreo & 43,934 & $-21.21 \%$ & -294 & 63 \\
\hline Mieres & 42,425 & $-26.98 \%$ & -349 & -357 \\
\hline Torrelavega & 55,125 & $-1.18 \%$ & -69 & -203 \\
\hline Aviles & 82,938 & $-4.21 \%$ & -311 & -66 \\
\hline \multirow[t]{2}{*}{ Ferrol } & 71,690 & $-21.88 \%$ & -317 & -355 \\
\hline & $\begin{array}{c}\text { Industrial } \\
\text { Employment } \\
(2007)^{(2)}\end{array}$ & $\begin{array}{c}\text { Unemployed workers } \\
\text { / persons 15-65 years } \\
(2011)^{(2)} \\
\end{array}$ & $\begin{array}{c}\text { Housing } \\
\text { vacancy rates } \\
(2011) \\
(1)\end{array}$ & $\begin{array}{c}\text { Housing prices } \\
\left(€ / \mathbf{m}^{2}\right) \\
(2011)^{(3)}\end{array}$ \\
\hline Barakaldo & $7.9 \%$ & $12.4 \%$ & $5.94 \%$ & $2,537.4$ \\
\hline Basauri & $30.5 \%$ & $12.2 \%$ & $8.98 \%$ & $2,559.2$ \\
\hline Portugalete & $7.9 \%$ & $11.6 \%$ & $6.44 \%$ & $2,654.7$ \\
\hline Santurzi & $11.2 \%$ & $13.4 \%$ & $7.48 \%$ & $2,548.7$ \\
\hline Langreo & $23.6 \%$ & $13.9 \%$ & $15.72 \%$ & 982.3 \\
\hline Mieres & $23.9 \%$ & $14.5 \%$ & $14.36 \%$ & $1,229.9$ \\
\hline Torrelavega & $15.2 \%$ & $14.4 \%$ & $14.15 \%$ & 1,366 \\
\hline Aviles & $24.0 \%$ & $12.6 \%$ & $11.67 \%$ & $1,401.8$ \\
\hline Ferrol & $15.3 \%$ & $15.7 \%$ & $19.78 \%$ & 979.7 \\
\hline
\end{tabular}

Source: Author's elaboration on data of: (1) Spanish Statistical Office (INE), (2) General Social Security Funds, and (3) Spanish Ministry of Public Works.

The analysis of the stock of workers in knowledge-intensive and creative industries reveals strong spatial polarisation patterns (the two big metropolises of Madrid and Barcelona account for more than one third of these workers). Old industrial cities present an extremely limited share in the country total (less than 0.5 per cent), confirming their weak economic position (Table 3). Accordingly, the importance of these workers with respect to local employment in old industrial cities is the lowest across the urban system: 5.32 per cent in cities with between 40,000 and 100,000 inhabitants; and 6.35 per cent for those with between 100,000 and 250,000 inhabitants. On the other hand, the creative occupations show a significantly lower concentration, with cities between 100,000 and 1 million inhabitants gaining share in general. 
Table 3 Stock and flow of creative workers across Spanish urban system (2011)

\begin{tabular}{|c|c|c|c|c|c|c|c|c|c|c|c|c|c|}
\hline \multirow{2}{*}{$\begin{array}{l}\text { Urban strata } \\
\text { (inhabitants) }\end{array}$} & \multirow[b]{2}{*}{ Type ${ }^{(1)}$} & \multicolumn{4}{|c|}{ Total workers } & \multicolumn{4}{|c|}{$\begin{array}{c}\text { Workers in knowledge-intensive and creative } \\
\text { industries }\end{array}$} & \multicolumn{4}{|c|}{ Creative occupations } \\
\hline & & Stock $^{(2)}$ & \% Spain & Net flow ${ }^{(2)}$ & $\%$ Stock & Stock $^{(2)}$ & $\%$ Spain & Net flow ${ }^{(2)}$ & $\%$ Stock & Stock $^{(2)}$ & $\%$ Spain & Net flow ${ }^{(2)}$ & $\%$ Stock \\
\hline \multirow{4}{*}{$\begin{array}{l}20,000- \\
40,000\end{array}$} & GC & - & - & - & - & - & - & - & - & - & - & - & - \\
\hline & OIC & - & - & - & - & - & - & - & - & - & - & - & - \\
\hline & ODC & - & - & - & - & - & - & - & - & - & - & - & - \\
\hline & Total & $6,019,400$ & 34.00 & $-75,650$ & -1.26 & 296,400 & 15.10 & $-27,075$ & -9.13 & 410,075 & 18.09 & $-14,025$ & -3.42 \\
\hline \multirow{4}{*}{$\begin{array}{l}40,000- \\
100,000\end{array}$} & $\mathrm{GC}$ & $2,471,000$ & 13.96 & $-6,800$ & -0.28 & 264,175 & 13.45 & 1,350 & 0.51 & 312,775 & 13.80 & 5,375 & 1.72 \\
\hline & $\mathrm{OIC}$ & 114,675 & 0.65 & -700 & -0.61 & 6,100 & 0.31 & -325 & -5.33 & 12,575 & 0.55 & -675 & -5.37 \\
\hline & ODC & 54,000 & 0.31 & 425 & 0.79 & 6,525 & 0.33 & -100 & -1.53 & 5,325 & 0.23 & -100 & -1.88 \\
\hline & Total & $2,639,675$ & 14.91 & $-7,075$ & -0.27 & 276,800 & 14.10 & 925 & 0.33 & 330,675 & 14.59 & 4,600 & 1.39 \\
\hline \multirow{4}{*}{$\begin{array}{l}100,000- \\
250,000\end{array}$} & $\mathrm{GC}$ & $2,726,250$ & 15.40 & 11,325 & 0.42 & 294,350 & 14.99 & $-3,250$ & -1.10 & 415,375 & 18.33 & 10,475 & 2.52 \\
\hline & $\mathrm{OIC}$ & 27,550 & 0.16 & -750 & -2.72 & 1,750 & 0.09 & -175 & -10.00 & 5,250 & 0.23 & 0,00 & 0.00 \\
\hline & ODC & 446,425 & 2.52 & 2,900 & 0.65 & 49,025 & 2.50 & -925 & -1.89 & 82,650 & 3.65 & 1,100 & 1.33 \\
\hline & Total & $3,200,225$ & 18.08 & 13,475 & 0.42 & 345,125 & 17.58 & $-4,350$ & -1.26 & 503,275 & 22.20 & 11,575 & 2.30 \\
\hline \multirow{3}{*}{$\begin{array}{l}250,000- \\
1,000,000\end{array}$} & $\mathrm{GC}$ & $2,429,475$ & 13.72 & 12,375 & 0.51 & 321,125 & 16.35 & 5,625 & 1.75 & 385,675 & 17.02 & 4,400 & 1.14 \\
\hline & ODC & 434,600 & 2.46 & 6,650 & 1.53 & 58,300 & 2.97 & 950 & 1.63 & 77,575 & 3.42 & 1,475 & 1.90 \\
\hline & Total & $2,864,075$ & 16.18 & 19,025 & 0.66 & 379,425 & 19.32 & 6,575 & 1.73 & 463,250 & 20.44 & 6,575 & 1.42 \\
\hline \multirow{3}{*}{$>1,000,000$} & $\mathrm{GC}$ & $1,877,275$ & 10.60 & 18,925 & 1.01 & 447,450 & 22.79 & 12,725 & 2.84 & 377,625 & 16.66 & $-6,300$ & -1.67 \\
\hline & ODC & $1,101,900$ & 6.22 & 28,100 & 2.55 & 218,325 & 11.12 & 10,600 & 4.86 & 181,625 & 8.01 & $-1,475$ & -0.81 \\
\hline & Total & $2,979,175$ & 16.83 & 47,025 & 1.58 & 665,775 & 33.91 & 23,325 & 3.50 & 559,250 & 24.67 & $-7,775$ & -1.39 \\
\hline
\end{tabular}

(1) GC: Growing Cities; OIC: Old industrial cites; ODC: Other declining cities

(2) Estimated figures (raising factor of 25). Stock in 2011, which includes workers without complete location history (15\% on average); Net flow between 2011 and 2007 (only for workers with complete location history)

Source: Authors' elaboration on CSWH 
Old industrial cities seem more attractive for highly qualified professionals than for workers in general or in knowledge creative industries, representing 10.97 per cent and 19.06 per cent respectively of the total workforce in each urban stratum considered.

In a general context of small cities acting as source regions and big dominant cities as net receivers, the negative net flow of workers affects old industrial cities in both urban strata. Cities with 40,000-100,000 inhabitants lost in 2011 -5.37 per cent of the existing stock in the knowledge-intensive and creative industries and -5.33 per cent in creative occupations; while cities with 100,000-250,000 inhabitants lost -10.00 per cent and 0.00 per cent respectively. The out-migration of talent clearly has a greater effect on them, even greater than for the rest of the workforce. Nevertheless, at the same time, they seem able to retain a substantial part of their stock of creative workers, including locally trained workers.

\section{The creative workers' profile in old industrial cities}

The number of people working in 2011 in the selected Spanish old industrial cities with a complete location history according to the CSWH is 4,166 . Table 4 and 5 classifies them again by activities and occupations respectively, differentiating at the same time workers in 2011 that were already in the city in 2007 from those arriving since then, regardless of any subsequent movements during the interim period.

Almost a quarter of the workers in knowledge-intensive and creative industries were born in a different Spanish region, while only 4.5 per cent were born in a different country. Although differences with respect to other sectors seem irrelevant, there are strong (and significant) internal contrasts. Thus, the percentage of workers born in a different region increases in the case of workers recently arriving in the city with respect to those that were already there (35.37 per cent versus 14.88 per cent), as well as the percentage of workers born abroad (7.41 per cent versus 2.48 per cent). In this regard, people from Latin American countries dominate, while European countries increase their weight among workers staying in the city.

The coincidence between the first place of work and the current one reveals that just 15.27 per cent of the workers in knowledge-intensive and creative industries initiated their working lives in the same cities. The percentage falls to just 1.21 per cent in the case of arriving workers, while the proportion rises to 24.79 per cent in staying workers. Altogether, the results suggest the existence of an underlying movement of workers born in the same region - probably in smaller rural towns who after their entry in the labour market move toward these old industrial cities searching for job opportunities. An important portion of workers may then get 'locked into' an immobile situation, as suggested in the literature. At the same time, the number of recent subsequent movements to return seems very limited. Some personal characteristics may explain the greater migration propensity of workers 
attracted recently, such as lower average age, the greater presence of women and, especially, of foreign immigrants.

Even though the presence of workers in knowledge-intensive and creative industries with tertiary education is significantly higher than in the rest of the economy (71.43 per cent vs 47.52 per cent), there is a difference (not significant) in favour of those staying. The same conclusions can be drawn for the share of workers occupying the most qualified occupations within firms. Indeed, almost eight employees out of ten in the knowledge-intensive and creative industries are low-skilled workers. On the other hand, the average income of workers in knowledge-intensive and creative industries seems to be lower than in other sectors and this difference is even greater in the case of arriving workers. This phenomenon is related to the massive low-skilled immigration observed in the country in the previous decade.

With regard to the origins of workers in creative occupations, the presence of foreign workers drops to 2.50 per cent of the total, while 79.44 per cent were born in the same region and 30.76 per cent initiated their working life in the same city. This percentage, which is two times that observed in the previous group, rises significantly in both staying and arriving workers. This confirms the existence of more job opportunities for highly qualified workers in general, propelling them either to stay or to come back.

The share of workers with at least a tertiary education is significantly higher than that observed in other occupations (89.74 per cent vs 41.12 per cent), albeit the internal differences in favour of arriving talented-workers seem again irrelevant. Some additional evidence can be obtained from information provided by the hiring institutions. In other occupations these cover a range of lower productivity activities in the services and construction sectors and with lower human capital and knowledge requirements. In contrast, creative occupations exhibit a higher degree of specialisation, with a significant amount of employment within the public sector, especially in Hospitals (24.11 per cent), State Administration (5.87 per cent) as well as Education (at different levels). At the same time there is a noticeable presence of activities in sectors that were once key to the economic model of these old industrial cities and that have subsequently been subject to restructuring, such as shipbuilding (9.43 per cent). Internally there would be a significant and negative difference in the presence of arriving workers dedicated to this latter sector, but the trend is positive in others such as retail activities. Finally, the average income is significantly higher than for other types of workers (€31,409.87 vs €18,703.39), reproducing internally the distance between staying and arriving workers. 
Table 4 Socio-professional profile of creative workers (by activities) in old industrial cities (2011)

\begin{tabular}{|c|c|c|}
\hline & $\begin{array}{l}\text { Knowledge-intensive and creative } \\
\text { sectors }\end{array}$ & Others sectors \\
\hline $\mathrm{N}$ & 203 & 3,963 \\
\hline Share of woman & $49.75 \%$ & $44.41 \%$ \\
\hline Average age & $38.83^{*}$ & $42.52 *$ \\
\hline $\begin{array}{l}\text { Principal countries of } \\
\text { born }\end{array}$ & $\begin{array}{l}\text { Spain }(95.5 \%), \text { Argentina }(0.99 \% *), \\
\text { Colombia }(0.50 \%) \text {, Ecuador }(0.50 \%), \\
\text { France }(0.50 \%) \text {, Rumania }(0.50 \%)(\ldots)\end{array}$ & $\begin{array}{l}\text { Spain }(94.9 \%) \text {, France } \\
(0.56 \%), \text { Colombia }(0.43 \%) \text {, } \\
\text { Ecuador }(0.43 \%) \text {, Rumania } \\
(0.33 \%)(\ldots)\end{array}$ \\
\hline $\begin{array}{l}\text { Same region of born- } \\
\text { current work }\end{array}$ & $76.85 \%$ & $78.35 \%$ \\
\hline $\begin{array}{l}\text { Same city of first } \\
\text { work-current work }\end{array}$ & $15.27 \% *$ & $25.74 \% *$ \\
\hline $\begin{array}{l}\text { Share of tertiary } \\
\text { education }\end{array}$ & $71.43 \% *$ & $47.52 \% *$ \\
\hline $\begin{array}{l}\text { Share of high } \\
\text { qualifications }\end{array}$ & $17.24 \%$ & $15.44 \%$ \\
\hline Principal activities & $\begin{array}{l}\text { (Knowledge-intensive and creative } \\
\text { industries: } 100 \% \text { ) }\end{array}$ & $\begin{array}{l}\text { Hospital activities }(8.10 \%) \text {, } \\
\text { Cleaning activities }(5.10 \%) \text {, } \\
\text { Administration of State and } \\
\text { economic \& social policy of } \\
\text { community (4.74), } \\
\text { Beverage serving activities } \\
(4.31 \%) \text {, Retail sale in } \\
\text { specialized stores }(3.71 \%) \text {, } \\
\text { Shipbuilding }(3,61 \%), \\
\text { Medical \& dental practice } \\
(3.33 \%), \text { Construction of } \\
\text { buildings }(3.05 \%)(\ldots)\end{array}$ \\
\hline $\begin{array}{l}\text { Income subject to } \\
\text { contributions }(€)\end{array}$ & $19,945.34$ & $20,719.22$ \\
\hline
\end{tabular}

\begin{tabular}{|l|l|}
\hline Knowledge-intensive and creative sectors \\
\hline Workers staying 2007-2011 & Workers arriving since 2007 \\
\hline 121 & 82 \\
\hline $54.55 \%$ & $42.68 \%$ \\
\hline $40.90^{*}$ & $35.77^{*}$ \\
\hline $\begin{array}{l}\text { Spain }(97.52 \%), \text { Germany }(0.83 \%), \\
\text { Rumania (0.83) (..) }\end{array}$ & $\begin{array}{l}\text { Spain }(92.59 \%) \text {, Argentina } \\
(2.47 \%), \text { Colombia }(1.23 \%), \\
\text { Dominican Republic }(1.23 \%), \\
\text { France (1.23\%) }(\ldots)\end{array}$ \\
\hline $85.12 \%^{*}$ & $64.63 \% *$ \\
\hline $24.79 \%^{*}$ & $1.21 \%^{*}$ \\
\hline $73.55 \%$ & $68.29 \%$ \\
\hline $18.18 \%$ & $15.85 \%$ \\
\hline $\begin{array}{l}\text { Knowledge-intensive and creative } \\
\text { industries: } 100 \%)\end{array}$ & $\begin{array}{l}\text { (Knowledge-intensive and } \\
\text { creative industries: } 100 \%)\end{array}$ \\
& \\
\hline $21,453.36^{*}$ & $17,692.61 *$ \\
\hline
\end{tabular}

* Significant mean/percentage differences according to Bonferroni test $(\mathrm{p}<.05)$

Source: Author's elaboration on CSWH 
Table 5 Socio-professional profile of creative workers (by occupations) in old industrial cities (2011)

\begin{tabular}{|c|c|c|}
\hline & Creative occupations & Others occupations \\
\hline $\mathrm{N}$ & 647 & 3,519 \\
\hline Share of woman & $54.56 \% *$ & $42.85 \% *$ \\
\hline Average age & $44.20 *$ & $41.99 *$ \\
\hline $\begin{array}{l}\text { Principal countries of } \\
\text { born }\end{array}$ & $\begin{array}{l}\text { Spain }(97.50 \% *) \text {, France }(0.47 \%) \text {, } \\
\text { Cuba }(0.31 \%) \text {, Peru }(0.31 \%)(\ldots)\end{array}$ & $\begin{array}{l}\text { Spain }(94.40 \% *), \text { Francia } \\
(0.57 \%), \text { Colombia }(0.52 \%) \text {, } \\
\text { Ecuador }(0.46 \%) \text {, Rumania } \\
(0.40 \%)(\ldots)\end{array}$ \\
\hline $\begin{array}{l}\text { Same region of born- } \\
\text { current work }\end{array}$ & $79.44 \%$ & $78.06 \%$ \\
\hline $\begin{array}{l}\text { Same city of first } \\
\text { work-current work }\end{array}$ & $30.76 \%$ & $24.21 \%$ \\
\hline $\begin{array}{l}\text { Share of tertiary } \\
\text { education }\end{array}$ & $89.74 \% *$ & $41.12 \% *$ \\
\hline $\begin{array}{l}\text { Share of high } \\
\text { qualifications }\end{array}$ & $(100 \%)$ & $15.50 \%$ \\
\hline Principal activities & $\begin{array}{l}\text { Hospital activities }(24.11 \% *), \\
\text { Shipbuilding }(9.43 \% *) \text {, Medical \& } \\
\text { dental practice }(8.81 \% *) \text {, Secondary } \\
\text { education }(6.18 \% *), \text { Administration of } \\
\text { State and economic \& social policy of } \\
\text { community }(5.87 \%) \text {, Primary education } \\
(3.86 \%) \text {, Other education }(2.47 \% *) \\
(\ldots)\end{array}$ & $\begin{array}{l}\text { Cleaning activities }(5.68 \% *), \\
\text { Beverage serving activities } \\
(4.86 \%) \text {, Hospital activities } \\
(4.69 \% *) \text {, Administration of } \\
\text { State and economic \& social } \\
\text { policy of community }(4.26 \%) \text {, } \\
\text { Retail sale in specialized } \\
\text { stores }(3.86 \% *) \text {, Construction } \\
\text { of buildings }(3.24 \% *), \text { Iron \& } \\
\text { steel manuf. }(2.44 \%)(\ldots)\end{array}$ \\
\hline $\begin{array}{l}\text { Income subject to } \\
\text { contributions }(€)\end{array}$ & $31,409.87^{*}$ & $18,703.39^{*}$ \\
\hline
\end{tabular}

\begin{tabular}{|c|c|}
\hline \multicolumn{2}{|l|}{ Creative Occupations } \\
\hline Workers staying $2007-2011$ & Workers arriving since 2007 \\
\hline 517 & 130 \\
\hline $52.22 \% *$ & $63.85 \% *$ \\
\hline $45.81 *$ & $37.78^{*}$ \\
\hline $\begin{array}{l}\text { Spain }(97.47 \%) \text {, France }(0.58 \%), \\
\text { Cuba }(0.39 \%) \text {, Peru }(0.19 \%)(\ldots)\end{array}$ & $\begin{array}{l}\text { Spain }(97.67 \%) \text {, Ecuador } \\
(0.78 \%), \text { Peru }(0.78 \%)(\ldots)\end{array}$ \\
\hline $82.01 \% *$ & $69.23 \% *$ \\
\hline $36.17 \% *$ & $9.23 \% *$ \\
\hline $89.69 \%$ & $89.92 \%$ \\
\hline$(100 \%)$ & $(100 \%)$ \\
\hline $\begin{array}{l}\text { Hospital activities }(24.76 \%), \\
\text { Shipbuilding }(11.22 \% *) \text {, Medical } \\
\& \text { dental practice }(8.70 \%), \\
\text { Secondary education }(6.58 \%), \\
\text { Administration of State and } \\
\text { economic \& social policy of } \\
\text { community }(5.61 \%), \text { Primary } \\
\text { education }(4.84 \%), \text { Rubber } \\
\text { products manuf. }(2.71 \%)(\ldots)\end{array}$ & $\begin{array}{l}\text { Hospital activities (21.54\%), } \\
\text { Medical \& dental practice } \\
(9.23 \%) \text {, Administration of } \\
\text { State and economic \& social } \\
\text { policy of community }(6.92 \%) \text {, } \\
\text { Secondary education }(4.62 \%) \\
\text { Iron \& steel manuf. (3.85\%), } \\
\text { Retail sale in specialized stores } \\
(3.85 \% *) \text {, Other education } \\
(3.08 \%) \text {, Shipbuilding } \\
(2.31 \% *)(\ldots)\end{array}$ \\
\hline $32,019.13^{*}$ & $28,991.74 *$ \\
\hline
\end{tabular}

* Significant mean/percentage differences according to Bonferroni test $(\mathrm{p}<.05)$

Source: Author's elaboration on CSWH 


\section{Conclusions and policy implications}

The goal of this research is to extend our knowledge about talent attraction and retention processes in structurally weak regions, such as Spain's old industrial cities. This perspective is gradually being included in all of their urban agendas, although to different degrees. Most of these cities seem to limit their efforts to providing job search and training services, while others concentrate on restoring local business competitiveness and innovation capacity as a way of increasing job opportunities. Sometimes they also attempt to attract talent by improving local living conditions and cultural facilities (i.e. the Niemeyer International Cultural Centre in Aviles). Barakaldo is one step ahead, since it has developed a more integrated and ambitious perspective as part of its Local Action Plan (linked to the URBACT II RUnUP project). 11 This includes actions to reinforce training programmes and the culture of entrepreneurship, as well as enhance firms' ability to collaborate, network and innovate. Living conditions are also being improved to attract skilled workers.

The economic foundations of such strategies seem to be clear but their effectiveness often remains unclear, especially the contribution to structurally changing the economic cycle of old industrial cities. These have been struggling for decades with industrial restructuring and economic diversification; the differences in their quest to become post-industrial cities are still noticeable. Furthermore, our evidence confirms that old industrial cities concentrate a very small portion of the country's employment stock in the knowledge-intensive and creative industries or in creative occupations, albeit the concentration of the latter workforce is higher. At the same time, the existence of a general flow is confirmed whereby workers are transferred from smaller and lagging cities to dominant, large urban areas.

The lack of job opportunities still represents the most influential explanatory factor. Accordingly, the importance of local manufacturing and business services in terms of employment - despite the restructuring or relocation processes that commonly affect these economies - favours clearly the attraction of qualified workers. Wherever the cities occupy a stronger metropolitan position, the weight of qualified employees increases since the presence of high-level urban functions increases; for example, in Barakaldo, Portugalete or Santurzi. In this regard, strengthening the inherited productive system could be a more effective way of anchoring locally talent, rather than the flagship cultural projects launched recently by the local governments of several of these cities. On the other hand, as the success may depend on the formulation of 'tailored-made' and 'target groups' programmes, it is crucial to look at personal characteristics and socio-professional profiles.

\footnotetext{
${ }^{1}$ The RUnUP project: 'Local Strategies for Talent Attraction and Retention' was part of the URBACT II European Program for Urban Sustainable Development. Ten cities participated in this initiative: Gateshead (United Kingdom), Barakaldo (Spain), Solna (Sweden), Campobasso (Italy), Patras (Greece), Leszno (Poland), Dunkerque (France), Potsdam (Germany), Águeda (Portugal).
} 
Our results emphasise the 'local' character of the creative workforce, with more than two thirds of workers born in the same region. An intraregional migration movement of workers from smaller towns searching for more job opportunities is feeding the economies of even old industrial cities, making it advisable to develop a regional scope in talent attraction policies. At the same time, the limited attractiveness of these cities for 'foreign' talent is confirmed, because most international immigrants in recent years have moved to large growing cities and/or different types of sectors/ occupations. However, a return flow exists for people who started their professional careers in these cities (it appears that women are prominent within these movements).

Nevertheless, what really matters to local economies is the characteristics of incomers. Some of the parameters analysed, such as qualifications or salaries, confirm the heterogeneity of arriving workers, bringing labour dualisation and precariousness even within knowledge-intensive and creative sectors (Sanchez-Moral et al., 2014). However, it seems clear that at least a group of qualified arriving workers have the potential to trigger knowledge spillovers and local pecuniary externalities, as shown by their education levels and incomes. Furthermore, many of the activities carried out by them have a greater knowledge and innovation content, highlighting their participation not only in traditional industrial sectors that have gone through restructuring (i.e. shipbuilding, iron and steel manufacturing), but also within the public sector (health, education, State administration), confirming its potential contribution to the improvement of local institutional frameworks.

Based upon these findings, further analyses would be needed to control some effects, such as the geographic origin of workers, or to model workers' movements in a more sophisticated way (i.e. considering intermediate yearly movements or workers' initial situation). In addition, case-study approaches can help to verify some of the hypotheses in relation to the local impact of talent flows.

\section{Acknowledgement}

This research forms part of R\&D Plans CSO2012-36170 and CSO2016-74888-C4-4R. Preliminary research was conducted in the framework of the Grant STSMTU0803-130612-018164.

\section{References}

ABER, J. and YAHAGI, H. (2014), 'Emerging regeneration strategies in the US, Europe and Japan', in K. Pallagst, T. Wiechmann and C. Martinez-Fernandez (eds), Shrinking Cities: International Perspectives and Policy Implications, New York, Routledge, 257-78.

BONTJE, M. and MUSTERD, S. (2008), 'The multi-layered city: the value of old urban profiles', Tijdschrift voor Economische en Sociale Geografie, 99, 248-55.

BOSCHMA, R. and FRITSCH, M. (2009), 'Creative class and regional growth: empirical evidence from seven European countries’, Economic Geography, 85, 391-424. 
DA VANZO, J. and MORRISON, P. A. (1981), 'Return and other sequences of migration in the United States', Demography, 18, 85-101.

EFILWC (EUROPEAN FOUNDATION FOR THE IMPROVEMENT OF LIVING AND WORKING CONDITIONS) (2006), Mobility in Europe. Analysis of the 2005 Eurobarometer Survey on Geographical and Labour Market Mobility, Dublin, EFILWC.

FAGGIAN, A. and MCCANN, P. (2009), 'Human capital and regional development', in R. Capello and P. Nijkamp (eds), Handbook of Regional Growth and Development Theories, Cheltenham, Edward Elgar, 131-51.

FLORIDA, R. (2005), Cities and the Creative Class, New York, Routledge.

FOL, S. and CUNNINGHAM-SABOT, E. (2010), 'Declin urbain et shrinking cities: une evaluation critique des approches de la décroissance urbaine', Annales de Géographie, $674,359-83$.

HOUSTON, D., FINDLAY, A., HARRISON, R. and MANSON, C. (2008), 'Will attracting the "creative class" boost economic growth in old industrial regions? A case study of Scotland', Geografiska Annaler: Series B, Human Geography, 90, $133-49$.

KEMPNER, R. T. (2008), 'The talent imperative for older industrial areas', in R. M. McGahey and J. S. Vey (eds), Retooling for Growth, Washington DC, The Brookings Institution, 61-87.

MUSTERD, S. and GRITSAI, O. (2012), 'The creative knowledge city in Europe: structural conditions and urban policy strategies for competitive cities', European Urban and Regional Studies, 20, 343-59.

PALLAGST, K., WIECHMANN, T. and MARTINEZ-FERNANDEZ, C. (2014), Shrinking Cities: International Perspectives and Policy Implications, New York, Routledge.

PLOGER, J. (2013), 'Comeback cities? Urban recovery approaches in European industrial cities', in C. Zimmermann (ed.), Industrial Cities - History and Future, Frankfurt/New York, Campus, 188-210.

PLOGER, J. and WECK, S. (2014), 'Confronting out-migration and the skills gap in declining German cities', European Planning Studies, 22, 437-55.

POWER, A., PLOGER, J. and WINKLER, A. (2010), Phoenix Cities: The Fall and Rise of Great Industrial Cities, Bristol, Policy Press.

SANCHEZ-MORAL, S., MENDEZ, R. and ARELLANO, A. (2014), 'Creative economy and employment quality in large urban areas in Spain', Urban Geography, 35, 264-89.

SANCHEZ-MORAL, S., MENDEZ, R. and PRADA, J. (2012), 'Avilés, entre el declive y la revitalizacion: ¿En la génesis de un nuevo modelo de desarrollo?’, Boletín de la Asociación de Geógrafos Españoles, 60, 321-48.

SCOTT, A. J. (2008), Social Economy of the Metropolis: Cognitive-Cultural Capitalism and the Global Resurgence of Cities, New York, Oxford University Press.

SHAPIRO, J. M. (2006), 'Smart cities: quality of life, productivity, and the growth effects of human capital', Review of Economics and Statistics, 88, 324-35.

SHIOJI, E. (2001), 'Composition effect of migration and regional growth in Japan', Journal of Japanese and International Economies, 15, 29-49.

SJAASTAD, L. A. (1962), 'The costs and returns of human migration', Journal of Political Economy, 70, 80-93. 